\title{
Питання психології
}

Шидлюх В., начальник відділу -заступник начальника управління ЦНДІ ЗСУ,

Серхіенко А., кандидат медичних наук, доцент, заступник Голови ВГО «Афганиі Чорнобиля» ORCID: 0000000219316764.

\section{ІНФОРМАЦЙНО-ПСИХОЛОГІЧНІ ВІЙНИ У СВІТЛІ О.О.С.}

У статті розглядаються питання теоретичних основ та практичного використання засобів інформаиійного протистояння з метою досягнення політичних $і$ військових иілей у міждержсвних відносинах на сучасному етапі розвитку світової спільноти.

Ключові слова: інформаційна війна, психологічна війна, психологічні комбінації, психологічні onepauiii.

В статье рассматриваются вопросы, связанные с теоретическими основами и практическим использованием средств информачионного противоборства для достижения политических и военных иелей в межбюджетных отночениях на современном этапе развития мирового сообщества.

Ключевые слова: информачионная война, психологическая война, психологические комбинации, психологические операчии.

Вступ. У статті розглядаються питання, пов'язані 3 теоретичними основами та практичним використанням засобів інформаційного протиборства 3 метою досягнення політичних та військових цілей у міждержавних стосунках на сучасному етапі розвитку світової спільноти.

Актуальність. Розвиток світової спільноти засвідчує, що в останній період критично важливим державним ресурсом, який все потужніше впливає на рівень національної безпеки, стає інформація. Вона циркулює в засобах масової інформації, автоматизованих системах управління та зв'язку, як цивільних так і військових, і стає об'єктом все більшої уваги.

Це пов'язано з тим, що прискорений розвиток комп'ютерних технологій не тільки значно сприяв підвищенню їх функціонування, але й відкрив додаткові можливості для деструктивного впливу на них з боку протидіючої сторони. Адже ці системи $\epsilon$ компонентом структури управління державою, економікою, фінансами, оборонною сферою.

Актуальність безпеки нашої держави саме у цій, інформаційній сфері, підтверджує прийняття Верховною Радою України Закону України "Про основи національної безпеки України" (BВР, 2003.№ 39, ст. 351).

Стислий огляд проблеми. Вплив на функціонування інформаційних систем 3 метою виводу їх із ладу, поширення в них інформації для прийняття рішень, які б відповідали інтересам того, хто здійснює підготовку такої інформації тощо, прийнято

визначати терміном інформаційнопсихологічна війна.

3 точки зору фахівців Пентагону, інформаційно-психологічна війна може бути визначена як сукупність різноманітних форм, методів і засобів впливу на людей 3 метою зміни у бажаному напрямку їх психологічних характеристик (поглядів, думок, ціннісних орієнтацій, настроїв, мотивів, установок, стереотипів поведінки), а також групових норм, масових настроїв $\mathrm{i}$ громадської свідомості в цілому. В деяких джерелах ці дії визначають також терміном інформаційне протиборство.

Керівництво США під цим терміном розуміє комплексний вплив на систему державного та військового управління протидіючої сторони, iї політичне та воєнне керівництво, який вже в мирний час призводив би до прийняття сприятливих для Сполучених Штатів рішень, а в ході війни повністю паралізував як державну, так i військову структуру управління противника.

Одночасно 3 наступальним впливом, інформаційне протиборство передбачає i надійний захист національної інформаційної інфраструктури держави.

На сьогодні у військовому відомстві США розроблено концепцію ведення інформаційної війни на двох рівнях: державному та військовому.

На державному рівні метою інформаційного протиборства, в широкому розумінні цього слова, $\epsilon$ послаблення позицій конкуруючих держав за рахунок інформаційного впливу на політичну, 


\section{Питання психології}

дипломатичну, економічну та інші сфери діяльності країни.

Під час ведення інформаційнопсихологічної війни психологічний вплив, який здійснюється на людей, може проводитись різноманітними засобами:

По-перше, це інформаційні засоби. Наприклад, у передвоєнний період керівництво держави через засоби масової інформації прагне сформувати у свого населення патріотичні погляди i переконання, забезпечити у масовій свідомості пріоритет цілей державної політики. В той же час вірогідний противник прагне прищепити населенню та військовослужбовцям цієї держави вигідні тільки йому протилежні за спрямуванням ідеї та настрої: розпалює націоналістичні забобони, незадоволення політичними чи економічними заходами керівництва держави, що нерідко призводить до зниження рівня морально-психологічного стану населення i особового складу збройних сил.

По-друге, психологічний вплив може здійснюватися військовими засобами. Наприклад, СРСР з метою психологічного тиску розташовував свої війська та ракети біля кордону 3 Китаєм, у В'єтнамі, на території Куби. США неодноразово намагались досягти своїх політичних цілей за допомогою демонстрації військової сили, направляючи військово-морські угруповання в різні райони світу.

По-третє, 3 метою психологічного впливу може використовуватися система торгових і фінансових санкцій, спрямованих на підрив економіки потенційного противника. Так, економічні санкції (в тому числі й від імені ООН) вводились проти Іраку, Югославії, Куби, Лівії, Судану та деяких інших країн. Ці дії тягнуть за собою значне зниження рівня життя більшості населення, побутові труднощі, зростання захворюваності, дефіцит продовольства i, як наслідок, масове незадоволення громадян існуючим ладом.

По-четверте, психологічний тиск може здійснюватися політичними засобами. До них можна віднести створення чи підтримку існуючих опозиційних партій та рухів 3 метою тиску на керівництво держави.

Інформаційні операції на державному рівні також можуть вирішувати завдання захисту національних інтересів, попередження міжнародних конфліктів, недопущення провокаційних та терористичних акцій, а також забезпечення безпеки національних інформаційних ресурсів.

На військовому рівні інформаційні операції являють собою комплекс заходів, які проводяться у масштабах збройних сил, їх видів, і $є$ складовою частиною воєнної кампанії. Вони спрямовані на досягнення інформаційної переваги над противником (у першу чергу - в управлінні військами) та на захист своїх систем управління.

Так, перед збройними силами США перед вторгненням до Іраку вперше було поставлено завдання впливати на противника ще в період загрози, тобто до початку бойових дій, для забезпечення вигідного для США спрямування процесів управління i прийняття рішень протидіючою стороною.

Зміст психологічного впливу реалізується шляхом проведення психологічних операцій. Психологічна операція (ПсО) - головний елемент психологічної війни. Ї̈ї проведення передбачає використання на практиці в умовах збройної боротьби складної сукупності узгоджених за метою, завданнями, регіоном, часом та об'єктами видів, форм, способів і прийомів інформаційно-психологічного впливу.

Зазвичай при правильному плануванні психологічні операції проводяться перед застосуванням воєнної сили, а потім супроводжують чи доповнюють іiі використання. Вони здійснюються в рамках державної політики, a їx військова i прикладна сторони узгоджуються i координуються 3 діяльністю відповідних державних закладів.

У залежності від мети, характеру, масштабу та змісту завдань, які вирішуються, психологічні операції підрозділяються за своїм рівнем на стратегічні, оперативні і тактичні, за часом проведення - на ті, які проводяться у мирний час (загрозливий) період, у воєнний час і в ході миротворчих операцій.

Крім того, за спрямуванням психологічні операції діляться на:

ПсО для введення противника в оману,

ПсО проти цивільного населення противника, 


\section{Питання психології}

ПсО на підтримку бойових дій,

ПсО з сприяння опозиційним силам та дисидентським рухам,

ПсО для здійснення культурної експансії і диверсій,

консолідуючі ПсО,

ПсО в ході миротворчих операцій.

Стратегічні ПсО мають глобальний характер i здійснюються протягом тривалого часу (від місяця до кількох років). Ці операції зазвичай мають яскраво виражений політичний характер, i, як правило, являють собою інформаційнопропагандистські кампанії, об'єктом яких може бути навіть уся світова спільнота, включаючи й населення власної країни. В ході проведення психологічних операцій стратегічного рівня широко використовуються друковані та електронні засоби масової інформації.

Головними цілями стратегічної операції $€$ здійснення тиску на воєнно-політичне керівництво противника для того, щоб воно прийняло вигідне для об'єкта рішення, а також підготовка громадської думки для сприйняття прямого збройного втручання у внутрішні справи іноземних держав.

Одними 3 основних способів впливу на стратегічному рівні $\epsilon$ психологічна ізоляція та дезінформація об'єкта впливу.

Психологічна ізоляція об'єкта включає в себе заходи в політичній, економічній та військовій галузях.

У політичній галузі це може бути дипломатичний вплив, який здійснюється на керівництво держав, сусідніх 3 об'єктом впливу. Так, в ході підготовки до операції у Гренаді в жовтні 1983 року, США створили військово-політичний союз східнокарибських країн, який виступив 3 різким засудженням політики керівництва Гренади. До цього союзу увійшли Антигуа і Барбуда, Домініка, Сент-Люсія, Сент-Вінсент та Гренадіни. Виникнення цього альянсу дозволило засобам масової інформації західних країн трактувати його з'яву як результат загального невдоволення карибських країн політикою М. Бішопа та його кабінету.

В економічній галузі психологічна ізоляція, як правило, впроваджується шляхом введення торгових і економічних санкцій та ембарго. Так, адміністрація Р. Рейгана використала свій вплив на Міжнародний валютний фонд,
Міжнародний банк реконструкції та розвитку i Міжамериканський банк розвитку, щоб не допустити надання фінансової допомоги Гренаді.

Психологічна ізоляція у військовій сфері зводиться, в основному, до демонстрації рішучості використати збройні сили з метою вирішення кризової ситуації.

Другим способом інформаційнопсихологічного впливу, який активно використовується 3 метою тиску на населення інших країн, $є$ дезінформація. Вона використовується для того, щоб в найкоротші строки переконати власне населення та світову спільноту у необхідності вирішення проблеми, яка виникла, силовими методами.

Вплив на політичних та військових лідерів, а також на керівників (найвидатніших представників) засобів масової інформації, культури і мистецтв супротивної сторони є важливим аспектом інформаційного протиборства в цілому i психологічної операції зокрема. У зв'язку з цим, наприклад, у США особливої уваги надається створенню колективних та індивідуальних моделей поведінки представників вищої i середньої ланки державного i воєнного керівництва, створенню так званих психологічних портретів керівників.

На оперативному рівні інформаційнопсихологічні операції проводяться для забезпечення успішного ходу операції чи кампанії в цілому, вирішення головних завдань операції. Їх мета - вплив на системи зв'язку, системи тилового забезпечення та бойового управління збройними силами 3 одночасним захистом аналогічних систем як власних збройних сил, так і збройних сил союзників.

Інформаціно-психологічні операції на тактичному рівні проводяться 3 метою забезпечення вирішення тактичних завдань. Вони, як правило, зосереджені на інформаційних системах та інформації, які стосуються бойового управління, розвідки, зв'язку, i безпосередньо забезпечують ведення бойових дій частинами i з'єднаннями противника. Одночасно вживаються заходи для захисту власних аналогічних систем та систем союзників.

Занурення українців в стан тотального стресу здійснюється декількома інструментами. 


\section{Питання психології}

Периий - це постійні загострення на фронті, що чередуються 3 періодами затишшя. Смикаючи людину, постійно або створюючи йому проблеми або знімаючи їх, можна довести будь-кого до нервового зриву. А ще - вбити у нього здатність власної мобілізації і волю до опору.

Другий - це створення внутрішнього напруження через заклики до «майдану», організацію масових протестів, блокад 3 загрозою енергосистемі, інших заходів, що створюють відчуття повної дестабілізації ситуації в країні i розвалу державних інститутів.

Tpemiŭ - це пропаганда 3 боку "опозиційних" ЗМI, які демонструють наше життя, як безпросвітний світ корупції, підвищення цін, руйнування економіки i всіляких "зРад" як з боку наших союзників, так i всередині країни. Коли людина відчуває, що перспектив у країни немає ніяких - мотивація до дії і боротьби вмирає.

Четвертий - це редакційна політика багатьох українських 3МI, що приділяють значне місце в ефірі і на сторінках видань кримінальним новинам. Українці весь час живуть в світі крові та жорстокості, безглуздих вбивств, аварій і катастроф. Причому, більшість 3 цих новин не $\epsilon$ соціально значущими i являють собою окремі випадки, але в сукупності створюють картинку повної безнадії, незахищеності і викликають відчуття наближення катастрофи.

Якщо слідувати відомій концепції Г. Сельє, існують три основні стадії стресу: тривоги, опору і виснаження.

\begin{tabular}{lccr}
\multicolumn{1}{c}{ Спочатку } & відбувається & повна \\
мобілізація & сил & організму, людина \\
знаходиться & в & стані напруги i
\end{tabular} настороженості, вона втягується в боротьбу i намагається адаптуватися до нових стресових умов. Так було у нас в 2014 році.

Потім настає стадія опору: ознаки тривоги практично повністю зникають, рівень опірності значно вище звичайного. Це ми пережили в 2015 і в 2016 році.

Остання стадія - виснаження, коли енергія вже вичерпана, а фізіологічний i психічний захист - зламані. Цей період у нас почався в 20162017 роках і триває в нинішньому.

Кожна людина по-різному переживає останню стадію стресу. Згідно з концепцією відомого психолога О. Мікшіка, існує три види реакції людей при досягненні межі "міцності" в критичних ситуаціях.

Перший тип людей «розпадається» на фізіологічному рівні - впадає в ступор від перевтоми, перестає реагувати на навколишні події і зовнішні подразники. Згідно I. Павлову, така реакція центральної нервової системи називається "позамежним гальмуванням" і несе в собі охоронні для організму функції. Сьогодні вона властива для тієї частини нашого суспільства, яка абстрагувалися від проблем 3 війною i замкнулася в собі.

Другий тип людей ламається на психічному рівні, втрачає силу волі, здатність думати i приймати рішення, адекватно оцінювати обстановку. Така реакція спостерігається у значної частини нашого громадянського суспільства, активістів, які перебувають в стані розгубленості і розчарування. Частина з них опустила руки, частина - повністю втратила здатність до критичного мислення і реагує на ситуацію на рівні рефлексів $\mathrm{i}$ понять "зрада" або "перемога". Від перших в боротьбі вже немає ніякого толку, другі легко піддаються впливу, маніпуляції і ними легко управляти 3 боку різними "вкиданнями".

Tретій тип людей ламається на соціально-психологічному рівні. При досягненні межі "міцності" такі люди зберігають свою фізичну i психічну мобілізованість, але зраджують своїм життєвим принципам і установкам. Так, люди, які спочатку включилися в боротьбу за моральними і ідейними переконаннями, починають діяти виключно у власних інтересах i, розчарувавшись в початкових цілях, прагнуть отримати максимум особистої вигоди 3 того, що відбувається. Приклади такого типу ми бачимо серед низки волонтерів, правоохоронців i військовиків, які займаються контрабандою, торгівлею з ворогом і т. ін.

Українське суспільство буде остаточно зламано, коли кількість тих, хто внутрішньо ще пручається, стане менше необхідного критичного мінімуму. Цей мінімум стрімко наближається, і якщо прямо зараз не вжити екстрених заходів, то за рік-два нас зламають остаточно.

Що має зробити держава в такій ситуації? 


\section{Питання психології}

По-перше, мінімізувати вплив новин 3 фронту на самовідчуття суспільства. Постійні відео про поховання наших загиблих воїнів, новини про загибель мирних жителів і обстріли наших територій лише погіршують ситуацію. Там, де не можна промовчати - потрібно максимально балансувати інформацію позитивними новинами про наші успіхи, перемоги i втрати ворога. Новини 3 фронту завжди повинні випромінювати виключно оптимізм.

По-друге, держава повинна налагодити комунікацію 3 суспільством i стати драйвером будь-яких ініціатив, перехопити таку ініціативу у будь-яких груп, що свідомо чи несвідомо створюють дестабілізацію всередині країни.

По-третє, необхідно прийняти не зовсім демократичні заходи до ЗМІ, які працюють на підрив психологічного стану суспільства, сіють паніку, настрої поразки, розчарування і безвір'я. Які це можуть бути заходи - повинні вирішити компетентні органи і профільні відомства. Але якщо негайно не ввести "воєнний стан" в нашому вільному і демократичному інформаційному просторі, то нас знищать нашими ж руками.

По-четверте, українські 3МI, які бажають добра країні і українському народу, повинні проявити свідомість і мінімізувати подачу абсолютно непотрібних i зайвих "кримінальних" новин. Всім зрозуміло, що негативні новини завжди викликають більше інтересу у публіки, ніж позитивні: така природа людини - реагувати на негатив i оцінювати ризики для себе в навколишньому середовищі. Але якщо ми будемо слідувати в руслі смаків публіки сьогодні, то завтра буде погано всім - i публіці, і самим ЗМІ, які намагалися догодити кому завгодно, тільки не національним інтересам.

\section{Висновок:}

Можна твердити, що цілі інформаційної війни зовсім інші, ніж війни в загальноприйнятому розумінні. Це не фізичне знищення противника і ліквідація його збройних сил, не знищення важливих стратегічних та економічних об’єктів, а широкомасштабне порушення роботи інформаційних, комунікаційних мереж i систем, часткове порушення економічної інфраструктури та підпорядкування населення країни, яка атакується, волі країни-переможця.

Більше того, в епоху інформаційних війн плани бойових операцій розробляються військовими разом 3 цивільними спеціалістами, причому нерідко останні відіграють в цьому провідну роль.

Інформаційна війна - найстрашніша i найефективніша. Вона дозволяє зламати i підпорядкувати будь-яке суспільство, яке не здатне збудувати захист проти такого впливу. I якщо наша держава не візьметься, нарешті, за інформаційну складову, то нам не допоможе ні нове озброєння, ні кредити Заходу, ні заклинання влади про те, що все йде за планом.

На завершення необхідно відзначити, що в теперішній час психологічні операції стали невід'ємною частиною воєнного мистецтва. Великий досвід, нагромаджений спеціалістами у цій галузі, знаходить своє практичне застосування в ході підготовки та ведення збройних конфліктів різної інтенсивності, що дозволяє підвищувати ефективність силового впливу при вирішені як міжнародних, так і внутрішніх проблем.

\section{Список використаних джерел}

1. Вісник Верховної Ради України.- 2003.- № 39.- С. 351.

2. Беглов С. И. Внешнеполитическая пропаганда.- М., 1993.

3. Вепринцев В.Б., Манойло А.В., Петренко А.И., Фролов Д.Б. Операции информационно-психологической войны: краткий энциклопедический словарь-справочник.M., 2005.

4. Крысько В. Г. Секреты психологической войны.- Мн., 1999.

5. Лайнбарджер П. Психологическая война.- М., 1962.

6. Морозов А.М. Психологическая война.- К., 1996.

7. Почепцов Г.Г. Теория и практика коммуникаций.- М., 1998.

8. . Почепцов Г.Г. Психологические войны.- М., 2000.

9. Расторгуев С. П. Информационная война.- Г.: Радио и связь, 1998.

10. Томпсон К. Программные средства защиты информации.-Г., 1993.- 117 с. 


\section{Питання психології}

11. Thomas P. Rona Weapon Systems and Information War.- Boeing Aerospace Co., Seattle, WA, 1976.

12. Joint Pub 3-13.1 Command and Control Warfare, DOD US, February 1996.

13. Joint Pub 3-13 "Information Operations", DOD US, December 1998.

\section{References}

1. Visny`k Verxovnoyi Rady`Ukrayiny`.- 2003.- \# 39.- C. 351.

2. Beglov S. Y'. Vneshnepoly`ty`cheskaya propaganda.- M., 1993.

3. Vepry`ncev V.B., Manojlo A.V., Petrenko A.Y'., Frolov D.B. Operacy`y`y’nformacy`onnopsy`xology`cheskoj vojnы: kratky`j эncy`klopedy`chesky`j slovar’-spravochny`k.- M., 2005.

4. Krыs `ko V. G. Sekretы psy`xology`cheskoj vojnы.- Mn., 1999.

5. Lajnbardzher P. Psy`xology`cheskaya vojna.- M., 1962.

6. Morozov A.M. Psy`xology`cheskaya vojna.- K., 1996.

7. Pochepczov G.G. Teory`ya y` prakty`ka kommuny`kacy`j.- M., 1998.

8. . Pochepczov G.G. Psy`xology`chesky`e vojnы.- M., 2000.

9. Rastorguev S. P. Y’nformacy'onnaya vojna.- G.: Rady’o y` svyaz', 1998.

10. Tompson K. Programmnыe sredstva zashhy' tы y’nformacy'y'.-G., 1993.- 117 s.

11. Thomas P. Rona Weapon Systems and Information War.- Boeing Aerospace Co., Seattle, WA, 1976.

12. Joint Pub 3-13.1 Command and Control Warfare, DOD US, February 1996.

13. Joint Pub 3-13 "Information Operations", DOD US, December 1998.

\section{SUMMARY}

INFORMATIONAL AND PSYCHOLOGICAL WAR AT THE LIGHT J.F.O.

The article deals with issues related to the theoretical bases and the practical use of the means of information confrontation in order to achieve political and military goals in intergovernmental relations at the present stage of development of the world community.

Keywords: information warfare, psychological warfare, psychological combinations, psychological operations. 